\title{
Making Good Decisions: Television and Young Children's Learning, A Parent Tip Sheet ${ }^{1}$
}

David C. Diehl and Stephanie C. Toelle ${ }^{2}$

Parents allow their young children to watch television for a variety of reasons - to entertain them, to have fun as a family, to provide learning, opportunities, and sometimes to keep children occupied while the parent take a break or gets other things done. Television is a reality of life for most American families and the challenge is for parents to figure out how much television and what kind young children should be watching.

Today, virtually every American family has at least one television and most children and adults watch TV on a daily basis. Television does impact children's learning, so parents need to decide what role the TV will play in the family. When families define their own rules and guidelines for television viewing, they can create an environment that fosters their children's learning and development.

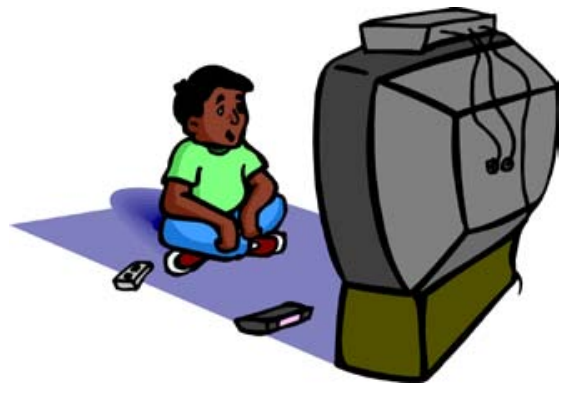

As young children sit and watch television, what are they learning? What can parents do to make television as positive as possible in the lives of their children?

\section{How Children Learn}

To help parents make good decisions about children's TV use, it is useful to start with what we know about how young children grow and learn. Research on early brain development has shown that while babies are born with billions of brain cells, stimulating activities are critical to healthy brain development and learning.

Some of the key things that infants, toddlers, and preschoolers need are:

- responsive, engaging, and stimulating interaction with their surroundings;

- exposure to language and sounds;

- adults who respond to their actions;

- the freedom and

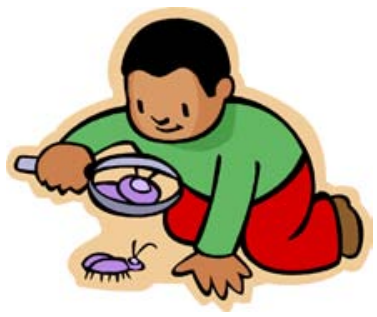
creativity that comes with play;

- the ability to explore the world and manipulate objects around them;

- guidance, structure, and support; and

- praise, affection, and positive feedback.

All of these things are best provided by other human beings, especially parents who care deeply about them. How, then, does television fit into children's learning?

1. This publication is FCS2292, one of a series of the Department of Family, Youth and Community Sciences, Florida Cooperative Extension Service, Institute of Food and Agricultural Sciences, University of Florida. Published December 2008. Please visit the EDIS Web site at http://edis.ifas.ufl.edu

2. David C. Diehl, Ph.D., assistant professor, Department of Family, Youth and Community Sciences, Cooperative Extension Service, Institute of Food and Agricultural Sciences, University of Florida, Gainesville, 32611. Stephanie C. Toelle, extension agent IV, Duval County Extension, Jacksonville, FL.

The Institute of Food and Agricultural Sciences (IFAS) is an Equal Employment Opportunity-Affirmative Action Employer authorized to provide research, educational information and other services only to individuals and institutions that function without regard to race, creed, color, religion, age, disability, sexual orientation, marital status, national origin, political opinions, or affiliation. For information on obtaining other extension publications, contact your county Cooperative Extension Service office. Florida Cooperative Extension Service/Institute of Food and Agricultural Sciences/University of Florida/Larry R. Arrington, Dean. 
Key Findings from Research ${ }^{1}$

What does research tell us about the effects of television on children's learning?

- Television viewing should be limited. The American Academy of Pediatrics (AAP) recommends that children under two years of age watch no television at all. Children older than this should watch no more than 1-2 hours of high-quality programming. Many young children are watching television more than the AAP recommends.

- Children can benefit from educational television. The effects of television largely depend on the type of programming children watch. Children who watch educational programming actually show learning gains, while those who watch more 'entertainment' programming learn less.

- Educational television can contribute to learning in a variety of ways. Educational television seems to contribute to vocabulary, counting, school readiness, and later grades in school.

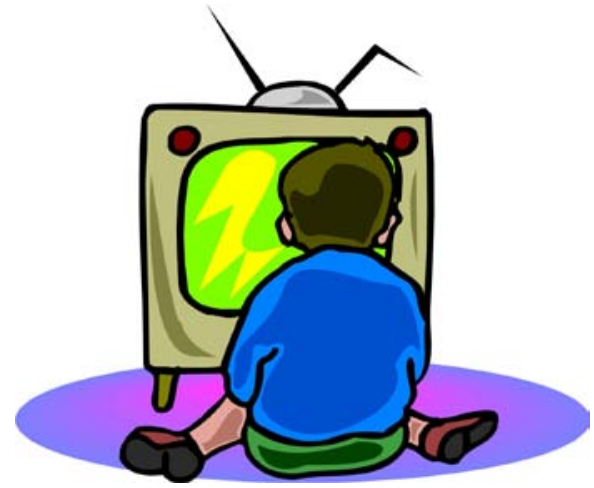

- Very young children (0-2) do not seem to benefit from television: Children under two years of age do not process television messages very well and do not learn as much from television as they do from social interactions with adults.

- Television may also interfere with children's learning. Young children who watch television may have more attention problems and also have more disrupted sleep, both of which can interfere with learning.

\footnotetext{
${ }^{1}$ For a more detailed review of the research, please see EDIS pub...
}

page 2

- Research has identified several children's programs that are educational. Sesame Street, Dora the Explorer, Blue's Clues, Arthur, Clifford, and Dragon Tales have all been found to encourage children's learning. Teletubbies, on the other hand, has been linked to slower language development in young children.

\section{What Parents Can $\mathrm{Do}^{2}$}

. Parents who take an active role in creating rules, boundaries, and expectations for television use are more likely to have children who benefit from media time. Here are some ways that parents can encourage their children to get the most out of the TV experience:

- Keep the television and computer out of children's rooms. Children who have a television in their room watch much more television than those who do not and it tends to be unsupervised.

- Set rules and boundaries. Families that have clear rules and expectations about media usage are more likely to control the amount of media exposure as well as the quality.

- Create family alternatives to television time. It is important to take some of children's media time and replace it with other family activities that encourage bonding, activity, and quality time together. Consider art projects, outdoor activities, sports, reading together, music, games, and other family activities.

- Choose positive programs that provide learning opportunities for children. Identify educational materials and encourage your children to watch them. To learn more about recommendations for educational materials, visit www.kidsfirst.org or www.commonsensemedia.org.

- Start creating strong learning habits early. Children learn habits at young ages, so if you

\footnotetext{
${ }^{2}$ These suggestions were adapted from a variety of resources, including: www.cmch.tv; www.mediafamily.org; and www.aap.org/advocacy/mediamatters.htm
} 
turn on the television every morning, your child will come to expect this. Work hard to make sure you are creating expectations that you value and that contribute to learning. For more information on early learning issues, visit the Born Learning website at www.bornlearning.org or Parenting 24/7 at www.parenting247.org.

- Emphasize learning in all aspects of life, not just television. Parents should recognize that television is only one factor in shaping children's learning experiences. Parents should actively encourage learning in all phases of life - through play, stories, reading, music, and all of the every-day experiences where children interact with and learn about the world.

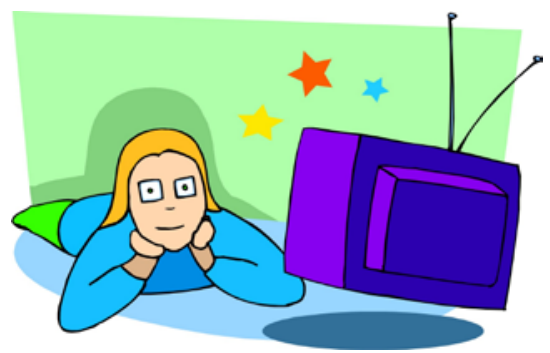

\section{Internet Resources for Parents}

The following are good resources for parents who want to learn more about the effects of media and what parents can do to encourage positive TV behaviors and early learning habits.

\section{American Academy of Pediatrics Media Matters}

(www.aap.org/advocacy/mediamatters.htm): Provides an overview of AAP's campaign about media and its effects on children as well as advocacy and policy statements, public education brochures, and presentations on media issues.

Born Learning (www.bornlearning.org):

Provides information on broader issues related to early learning for children and provides tips and resources for parents.

Center for Media Literacy (www.medialit.org): Provides resources on teaching children media literacy skills, specifically to critically question the messages that are presented to them (appropriate around 4-5 years old).

Center on Media and Child Health (www.cmch.tv): Created by Children's Hospital Boston, Harvard Medical School and Harvard School of Public Health, provides fact sheets for parents, teachers, and researchers.

\section{Coalition for Quality Children's Media} (www.kidsfirst.org): Provides reviews and recommendations on educational and informative movies, videos, audio, TV programs, and CDROMS.

\section{CommonSense Media}

(www.commonsensemedia.org): Provides resources and reviews of movies, TV shows, games, music, books, and web sites (relevant to young children as well as older children and adolescents).

MediaWise (www.mediafamily.org): Provides fact sheets, newsletters, and other resources on media and family issues.

Parenting 24/7 (www.parenting247.org): This website from Illinois Cooperative Extension provides resources for parents, including news, information, video clips, and advice on parenting and family life from birth through the teens.

\section{PBS Children and Media site}

(www.pbs.org/parents/childrenandmedia):

Provides resources on children and the media, including articles and tips for parents of preschoolers, grade schoolers, pre-teens, and teens.

PBS Kids (http://pbskids.org): Offers music, videos, and games for young children that are based on PBS shows, including Arthur, Cyberchase, Maya and Miguel, and others.

\section{Solutions for your Life}

(http://solutionsforyourlife.com): This is the Web site of University of Florida Cooperative Extension. It contains useful research-based resources on a variety of topics, including parenting, health and nutrition, financial 
Parent Tip Sheet: Television and Young Children's Learning

management, and other family and consumer

issues. 